\title{
Enzymatic Chromium (VI) Reduction by Cytoplasmic and Cell Membrane Fractions of Chromate-Reducing Bacterium Isolated From Sewage Treatment Plant
}

\author{
Paul Fabrice Nguema $^{1}$, Zejiao Luo ${ }^{1} \&$ Jing Jing Lian ${ }^{1,2}$ \\ ${ }^{1}$ State Key Laboratory of Bio geology and Environmental Geology, Ministry of Education (BGEG), School of \\ Environmental Studies, China University of Geosciences, Wuhan, China \\ ${ }^{2}$ Schools of Earth Environment and Water Resources, Yangtze University, Wuhan, China \\ Correspondence: Zejiao Luo, School of Environmental Studies, China University of Geosciences, 388 Lumo Lu, \\ Wuhan 430074, China. Tel: 86-134-7621-2088. E-mail: zjluo@cug.edu.cn
}

\author{
Received: December 24, 2013 Accepted: February 6, 2014 Online Published: February 17, 2014 \\ doi:10.5539/ijb.v6n2p64 \\ URL: http://dx.doi.org/10.5539/ijb.v6n2p64
}

\begin{abstract}
Hexavalent chromium is a toxic heavy metal in environment. To remove it from the system, reduction to the trivalent form using microorganisms is an alternative cost-effective method compared to the conventional physicochemical methods. Bacillus cereus Pf- 1 was isolated and tested for the reduction potential of Cr (VI) using different sub-cellular fractions. Diphenylcarbazide method was used to measure the remaining Cr (VI) concentration in supernatant after centrifugation, and the pellet was used for Scanning Electron Microscopy (SEM) and Energy Dispersive X-ray (EDX) analysis. Almost complete reduction of Cr (VI) was reported for initial $\mathrm{Cr}(\mathrm{VI})$ concentration from $10-50 \mathrm{mg} / \mathrm{L}$. Assay with permeabilized cells (treated with Toluene and Triton $\mathrm{X}-100)$ and cells free assay demonstrated that $\mathrm{Cr}$ (VI) reduction activity was mainly associated with the cytoplasmic fraction of the cells. Considering the major amount of $\mathrm{Cr}$ (VI) being reduced within $24 \mathrm{~h}$, the chromate reductase could have been released during growth. Additionally, SEM analysis showed that Bacillus cereus treated with $\mathrm{Cr}$ (VI) grew well and had uniform size. EDX analysis revealed certain amounts of chromium in cells treated with $\mathrm{Cr}(\mathrm{VI})$. Based on this, Bacillus cereus $\mathrm{Pf}-1$ could be considered as a potential reducing agent for $\mathrm{Cr}(\mathrm{VI})$ in aqueous solutions.
\end{abstract}

Keywords: Bacillus cereus Pf-1, chromate-reductase, cytoplasmic fraction, membrane fraction

\section{Introduction}

Hexavalent chromium is a toxic heavy metal with corrosion resistance properties such as electroplating, textile dying, metal processing and wood treatment (Ibrahim et al., 2012) which is widely used in several industries. Chromium exists in several oxidation states but only trivalent $(+3)$ and hexavalent $(+6)$ forms are usually encountered in the environment, depending on the local redox conditions (Gheju \& Balcu, 2010). Chromium compounds exhibit high mobility in the environment and exert toxic effects to most living organisms. The United States Environmental Protection Agency (2012) reported hexavalent chromium as one among the 17 chemicals posing as threat to humans. In contrast, the trivalent form is sparingly soluble, and has a stable oxidation property and thus less toxic (Ilias et al., 2011). It therefore implies that, removal of hexavalent chromium contaminant from polluted industrial aqueous effluents is an important step in pollution control of surface water and groundwater.

Several microorganisms have the exceptional ability to survive in noxious metal-polluted environments by developing mechanism like metal resistance plasmids, metal efflux channels, adsorption uptake, DNA methylation, and metal biotransformation either directly by enzymatic reduction to less mobile and non-toxic forms or indirectly through complexes formation with metabolites (Pei et al., 2009). Varieties of Cr-resistant with high potential of Cr (VI) reducing ability includes Agrobacterium, E. coli, Shewanella, Enterobacter, Thermus, Pseudomonas, Bacillus (Soni et al., 2013). However, Cr (VI) resistance and Cr (VI) reduction have been considered to be unrelated (Ohtake et al., 1987). The availability of selected strains able to resist and reduce chromate/dichromate increased the possibility of employing microorganisms for bioremediation of $\mathrm{Cr}$ (VI) contaminated sites. 
There are different types of $\mathrm{Cr}$ (VI) reduction enzymes in bacteria with $\mathrm{Cr}$ (VI) reductase, aldehyde oxidase, cytochrome P450, DT-diaphorase (Patra et al., 2010) as prominent examples. Similarly, several oxidoreductases with different metabolic functions have also been reported to catalyze $\mathrm{Cr}$ (VI) reduction in bacteria, which include nitroreductase (Kwak et al., 2003), iron reductase, quinone reductases (Gonzalez et al., 2005) as well as flavin reductases (Ackerley et al., 2004).

Enzymatic reduction of chromium (VI) using bacteria has recently received much attention. However, a lot still needs to be done to fully understand the mechanisms that govern chromium (VI) reduction by bacteria.

The purpose of this study was to explore the localization and mechanisms associated with $\mathrm{Cr}$ (VI) reduction by Bacillus cereus strain Pf-1 isolated from dewatering sludge, with high chromate reduction activities. The optimum conditions as well as the efficiency of $\mathrm{Cr}(\mathrm{VI})$ reduction due to the presence of electron donors and proteins denaturants were also investigated.

\section{Material and Methods}

All the chemicals were of reagent grade and were used without further purification. Unless otherwise stated, all the chemicals were purchased from Sinopharm Group Chemical Reagents Co. Ltd., Shanghai, China, Fisher (Fair Lawn, Nanjing), and Tianjin Fu Chen Chemical Reagents Factory, Tianjin, China.

\subsection{Isolation of Bacterial Strains}

Dewatering sludge samples were obtained from the Chinese Academy of Agricultural Sciences Sewage treatment plant Wuhan, China. The samples were collected in sterile containers, while being maintained below $4{ }^{\circ} \mathrm{C}$, in our laboratory until use. Isolation of bacterial strains was done by the enrichment culture technique. Nutrient Broth was amended with $30 \mathrm{mg} \mathrm{Cr}(\mathrm{VI}) / \mathrm{L}$ as $\mathrm{K}_{2} \mathrm{Cr}_{2} \mathrm{O}_{7}$ and $10 \%(\mathrm{v} / \mathrm{v})$ soil suspension $(10 \%$, w/v) prepared in sterile distilled water, which was incubated at $30^{\circ} \mathrm{C}$ for 24 hours under orbital shaking $(100 \mathrm{rpm})$. The $\mathrm{Cr}$ (VI) stock solutions were filtered and sterilized using a $0.22 \mu \mathrm{m}$ membrane filter (Q/IEFJ01-1997, China). These isolated strains (6 in total) were evaluated for their tolerance to $\mathrm{Cr}(\mathrm{VI})$ at different concentrations $(40-120 \mathrm{mg} / \mathrm{L})$. On the basis of the chromium tolerance test, the higher Cr-tolerance strain was selected for further analysis.

\subsection{Chromium (VI) Concentration Effect on Bacterial Growth and Chromium (VI) Reduction}

Individual culture flasks $(250 \mathrm{ml})$ containing $50 \mathrm{ml} \mathrm{NB}$, pH $7.0 \pm 0.3$, supplemented concentrations of $\mathrm{Cr}(\mathrm{VI})$ at $10,30,50$, and $100 \mathrm{mg} / \mathrm{l}$, were inoculated with $1 \mathrm{~mL}$ of bacterial cells cultured for $24 \mathrm{~h}$ at $30^{\circ} \mathrm{C}$ with constant shaking at $100 \mathrm{rpm}$. The cultures including biotic [NB without $\mathrm{Cr}$ (VI)] and abiotic [NB with $\mathrm{Cr}$ (VI) but not inoculated with bacteria] were cultured as controls. The density of the bacteria was monitored at definite time intervals by the viable plate count method. To measure the $\mathrm{Cr}(\mathrm{VI})$ reduction, $10 \mathrm{~mL}$ culture from each of above flasks were centrifuged $(10,000 \times \mathrm{g}$ for $10 \mathrm{~min})$ and the supernatant was analyzed using Diphenylcarbazide (DPC) reagent as described by Ishibashi et al. (1990). Briefly, the Cr (VI) containing samples (in the range 1-10 microgram) were acidified by adding $330 \mu \mathrm{l}$ of $6 \mathrm{~N}$ sulfuric acid. To this acidified solution of $\mathrm{Cr}$ (VI), $0.25 \%$ of DPC was added and the final volume was made up to $10 \mathrm{~mL}$. The mixture was incubated for $10 \mathrm{~min}$ at room temperature for the color development, thereafter; the complex was measured at $540 \mathrm{~nm}$ with spectrophotometer (WFZ800-D3B UV/VIS Spectrophotometer, Guangzhou, China).

\subsection{Effect of Temperature and $\mathrm{pH}$ on $\mathrm{Cr}$ (VI) Reduction}

Chromium (VI) reduction was studied at different temperatures $\left(20,30,40\right.$, and $\left.45^{\circ} \mathrm{C}\right)$ and $\mathrm{pH}(5,6,7,8$, and 9$)$. The initial $\mathrm{pH}$ was adjusted using $10 \%(\mathrm{v} / \mathrm{v}) \mathrm{HCl}$ or $10 \%(\mathrm{w} / \mathrm{v}) \mathrm{NaOH}$. Appropriate buffers $(50 \mathrm{mM})$, phosphate buffer ( $\mathrm{pH}$ 7.2) and Tris-HCL buffer ( $\mathrm{pH}$ 7.0) were added to avoid $\mathrm{pH}$ shift (Olajuyigbe \& Ajele, 2005). Flasks containing $50 \mathrm{~mL} \mathrm{NB}$ amended with $\mathrm{K}_{2} \mathrm{Cr}_{2} \mathrm{O}_{7}$ to final concentration of $30 \mathrm{mg} \mathrm{Cr}(\mathrm{VI}) / \mathrm{L}$ and control cultures were incubated as mentioned above. All the cultures including biotic and abiotic controls, in triplicate, were incubated as mentioned earlier. Aliquots of the cultures $(10 \mathrm{~mL})$ were withdrawn at regular time intervals from each replicated tube and centrifuged as mentioned earlier. The concentration of $\mathrm{Cr}$ (VI) in the supernatant was analyzed as mentioned earlier. Experiments were conducted in triplicates and were repeated twice.

\subsection{Resting Cell Assay}

Bacterial culture in $50 \mathrm{~mL} \mathrm{NB}$ was grown overnight at $30{ }^{\circ} \mathrm{C}$ with orbital shaking at $100 \mathrm{rpm}$. Cells were harvested from the culture by centrifugation at $10,000 \times \mathrm{g}$ for $10 \mathrm{~min}$. The pellets were washed thrice with phosphate buffer $(\mathrm{pH} 7.2)$ and re-suspended in the same buffer. These cell suspensions were spiked with $30 \mathrm{mg}$ $\mathrm{Cr}(\mathrm{VI}) / \mathrm{L}$ and adjusted the final volume to $10 \mathrm{~mL}$. The tubes were vortexed for $2 \mathrm{~min}$ and incubated for $12 \mathrm{~h}$. Samples were withdrawn at regular time intervals $(2,4,6,8,10$, and $12 \mathrm{~h}$ ) and the remaining $\mathrm{Cr}$ (VI) concentrations were measured as mentioned above. $\mathrm{Cr}$ (VI) spiked in heat-treated $\left(100{ }^{\circ} \mathrm{C}\right.$ for $\left.30 \mathrm{~min}\right)$ 
re-suspended cells served as controls.

\subsection{Permeabilized Cell Essay}

Bacterial cell permeabilization was carried according to previously reported protocols (Mangaiyarkarasi et al., 2011). Bacterial cell was grown for $24 \mathrm{~h}$, harvested and washed thrice with phosphate buffer. The suspended cells were treated with Toluene and Triton X-100 at final concentrations of 0.1, 0.2, 0.5, 1 and 2\%, and vortex for $20 \mathrm{~min}$. Cr (VI) reduction was initiated by adding $2 \mathrm{~mL}$ of these permeabilized cells suspensions to $8 \mathrm{~mL}$ of 50 $\mathrm{mM}$ phosphate buffer containing $\mathrm{Cr}(\mathrm{VI})(30 \mathrm{mg} / \mathrm{L})$ and glucose $(1 \%)$, and incubated at $30{ }^{\circ} \mathrm{C}$ in a water bath shaker for $12 \mathrm{~h}$. Samples were withdrawn at regular time intervals $(2,4,6,8,10$, and $12 \mathrm{~h})$, the reaction mixture was pelletized and the supernatant was analyzed for residual $\mathrm{Cr}(\mathrm{VI})$ concentration.

\subsection{Cell-Free Assay and Localization of Chromate Reduction Activity}

Cells were harvested at $10,000 \times \mathrm{g}$ after $24 \mathrm{~h}$ culturing, and washed thrice with phosphate buffer. These cells were re-suspended in phosphate buffer and disrupted using an ultrasonic probe according to Cheung et al. (2006). The cell lysates obtained were then centrifuged at $160,000 \times \mathrm{g}$ for $40 \mathrm{~min}$ at $4{ }^{\circ} \mathrm{C}$, and filtrated through $0.22 \mu \mathrm{m}$ filters. The supernatant of the cytosolic obtained was used as source of soluble enzyme. The sonicated cell debris was washed thrice with phosphate buffer and accordingly re-suspended in $8 \mathrm{ml}$ of buffer. Aliquots $(2 \mathrm{ml})$ of cell-free extract (CFE) or membrane fraction (CM) were used for enzymatic assay in order to localize the chromate reduction activity of the isolated either in extracellular, cytosolic or membrane-associated enzyme, respectively.

Chromate reduction was estimated using a standard calibration curve of $\mathrm{Cr}$ (VI) with reference to $\mathrm{K}_{2} \mathrm{Cr}_{2} \mathrm{O}_{7}$. Protein concentrations of CFE were estimated using Bradford (1976) reagent and specific activity was defined as unit chromate reductase per milligram protein concentration. Known concentrations of bovine serum albumin (BSA) prepared in phosphate buffer were used for standard calibration curve.

\subsection{Effect of Electron Donors and Proteins Denaturants on Cr (VI) Reduction by Cell-Free Extract}

Hexavalent chromium reductase activity in the cell-free extract of bacterial isolate was determined in the presence of (NADH, glucose, succinate, citrate, urea, and thiourea) at the final concentration of $0.1 \mathrm{mM}$ and incubated for $30 \mathrm{~min}$ at $30^{\circ} \mathrm{C}$. Cr (VI) concentration in the medium was $30 \mathrm{mg} / \mathrm{L}$.

\subsection{Extraction of DNA From Bacterial Culture and Amplification of $16 \mathrm{~S} \mathrm{rDNA}$}

Bacterial genomic DNA was isolated from overnight grown cells using standard procedures (Chachaty \& Saulnier, 2000). The extracted DNA was electrophoresed on $0.8 \%$ agarose gel in TAE buffer and visualized under UV in Uvitec to check for integrity. The quantity of extracted DNA was checked with a spectrophotometer.

Gene fragments specific for the highly variable V3 region of the bacterial $16 \mathrm{~S}$ ribosomal DNA gene was amplified by PCR as described by Ovreas et al. (1997) using universal bacterial primers $7 \mathrm{f}$ and $1540 \mathrm{r}$ with their respective oligonucleotide (5'-CAGAAGTTTGATCCTGGCT-3') and (5'-AGGAGGTGATCCAGCCGCA-3'). The PCR products were subjected to $2 \%$ agarose gel electrophoresis stained with ethidium bromide and visualized on a UV transilluminator for the presence of about $200 \mathrm{bp} \mathrm{PCR} \mathrm{products.} \mathrm{Amplified} \mathrm{16S} \mathrm{ribosomal}$ DNA gene PCR products were purified using strataprep ${ }^{\circledR}$ PCR purification kit (stratagene, USA) according to the manufacturer's protocol. Sequencing reactions were carried out using ABI-prism big dye terminator cycle sequencing ready reaction kit and the PCR products were purified by a standard protocol. The purified cycle sequenced products were analyzed with an ABI-prism 3730 genetic analyzer. The chromatogram sequencing files were edited using Chromas 2.32. Obtained 16S rDNA sequences were BLAST in NCBI using BLASTn program (http://www.ncbi.nih.gov/BLAST/). Sequences were aligned using CLUSTALW program (http://www.ebi.ac.uk/clustalw). Aligned sequences were used and phylogenetic tree constructed with the aid of Molecular Evolutionary Genetics Analysis (MEGA version 5.05) software based on Kimura 2-parameter evolutionary distances and evaluated by performing bootstrap analyses of 1000 replicates, to show the genetic relatedness of the isolate (Tamura et al., 2011).

\subsection{SEM-EDX Analysis}

The strain was cultured for $24 \mathrm{~h}$ in the medium without and with $\mathrm{Cr}(\mathrm{VI})[30 \mathrm{mg} / \mathrm{L}]$. After being centrifuged at $10,000 \times \mathrm{g}$ at $4{ }^{\circ} \mathrm{C}$, the cells were observed by SEM (model- Zeiss EVO40) and EDX (EDAX, USA).

\subsection{Statistical Analysis}

Experimental data, presented as mean \pm standard error (SE) in table and with bars in figures, were analyzed using Student's $t$ test and expressed at 0.05 probability level calculated by Origin version 8.5 . 


\section{Results}

\subsection{Screening and Identification of Bacterial Isolate}

Sequence similarity search was performed with obtained 16S rDNA sequences through BLAST-n program in NCBI. BLAST-n results revealed that our isolated strain namely Pf-1 belong to Bacillus and exhibited 99\% similarities with Bacillus cereus (GenBank accession number GU321330). Phylogenetic analysis position in relation to other related organisms have been shown in Figure 1. Our sequence has been submitted to the NCBI GenBank under accession number (KC152883).

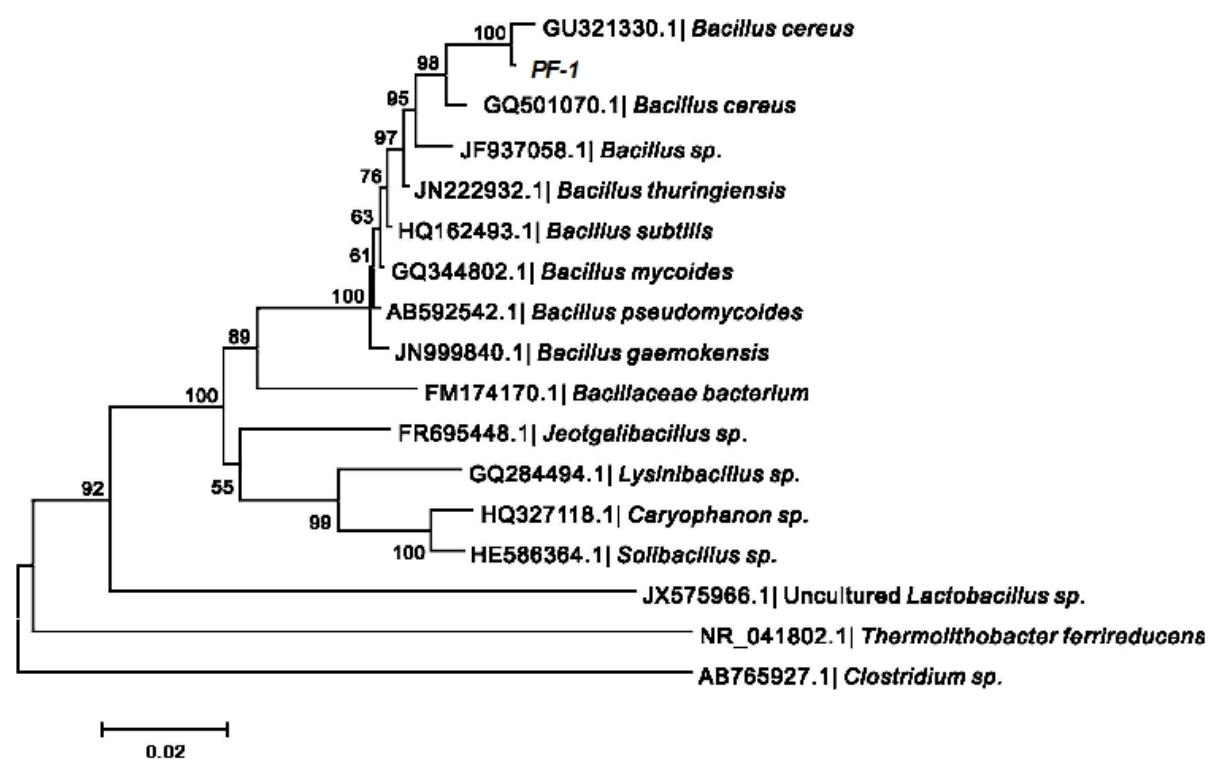

Figure 1. Phylogenetic tree constructed from the 16S rDNA gene of strain Pf-1 using neighbor-joining algorithm.

Accession numbers are given before the strains name, and scale bar represents 1 base substitution per 20 nucleotide positions. The bootstrap probabilities calculated from 1,000 replications. Clostridium sp. (AB765927) was taken as an out-group

Table 1 shows different isolated strains in our dewatering sludge samples and their minimum inhibitory concentration (MIC).

Table 1. MIC values for different isolates

\begin{tabular}{cc}
\hline Strains & MIC $(\mathrm{mg} \mathrm{Cr}(\mathrm{VI}) / \mathrm{L})$ \\
\hline Pf-1 & 60 \\
SS1 & 30 \\
Mp9 & 30 \\
Zc5 & 20 \\
Ng2 & 20 \\
NN3 & 20 \\
\hline
\end{tabular}

\subsection{Cr (VI) Reduction and Growth of Bacterial Strain}

The concentration of $\mathrm{Cr}(\mathrm{VI})$ affected bacterial growth and $\mathrm{Cr}(\mathrm{VI})$ reduction. As the concentration of $\mathrm{Cr}(\mathrm{VI})$ increased from $10-100 \mathrm{mg} / \mathrm{L}$, the $\mathrm{CFU}$ decreased from $4.5 \times 10^{5}-1.1 \times 10^{5}$ (Figure 2). At the same time the reduction efficiency decreased from $100 \%-55 \%$ (Figure 3). There were negligible levels of chromate reduction in abiotic controls. 


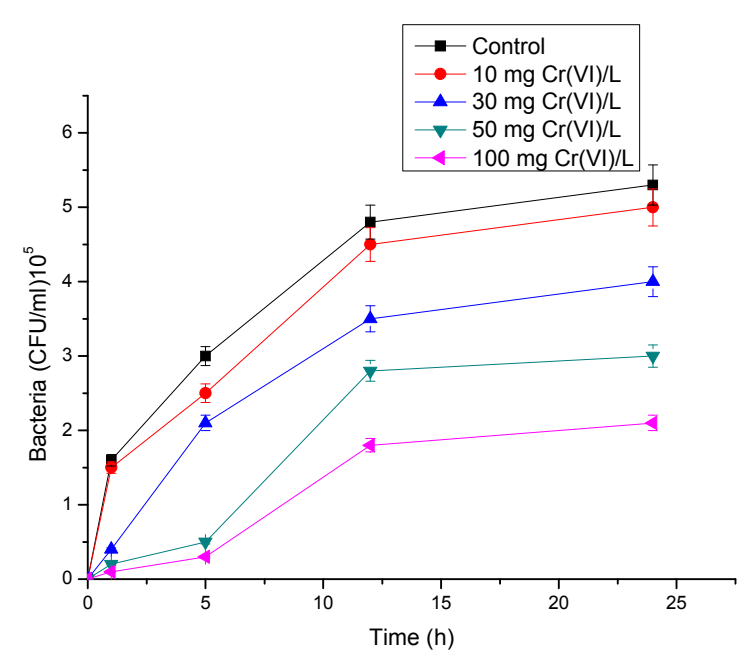

Figure 2. Growth of Bacillus cereus Pf-1 in NB medium amended with different $\mathrm{Cr}$ (VI) concentrations. NB medium with $10 \mathrm{mg} \mathrm{Cr}(\mathrm{VI}) / \mathrm{L}$ without bacterial inoculation as control

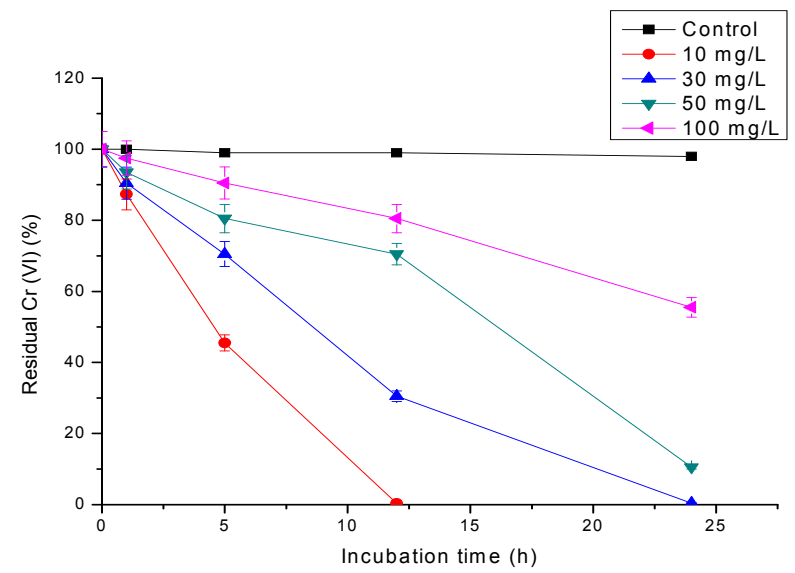

Figure 3. Kinetic of $\mathrm{Cr}$ (VI) reductions by Bacillus cereus Pf-1

\subsection{Effect of $p H$ and Temperature on Cr (VI) Reduction by Bacterial Strain}

The strength of $\mathrm{Cr}$ (VI) reduction was found to be affected by strain identity, temperature, $\mathrm{pH}$, and time. Chromate reduction was investigated at regular time intervals with variation of both temperature and $\mathrm{pH}$ (Figure 4). Maximum $\mathrm{Cr}(\mathrm{VI})$ reduction activity was established at $30^{\circ} \mathrm{C}$ and $\mathrm{pH} 7.0$, this activity decreased at both lower $\left(20^{\circ} \mathrm{C}\right)$ and higher $\left(45^{\circ} \mathrm{C}\right)$ temperatures. Negligible $\mathrm{Cr}(\mathrm{VI})$ reduction was observed in abiotic control. 

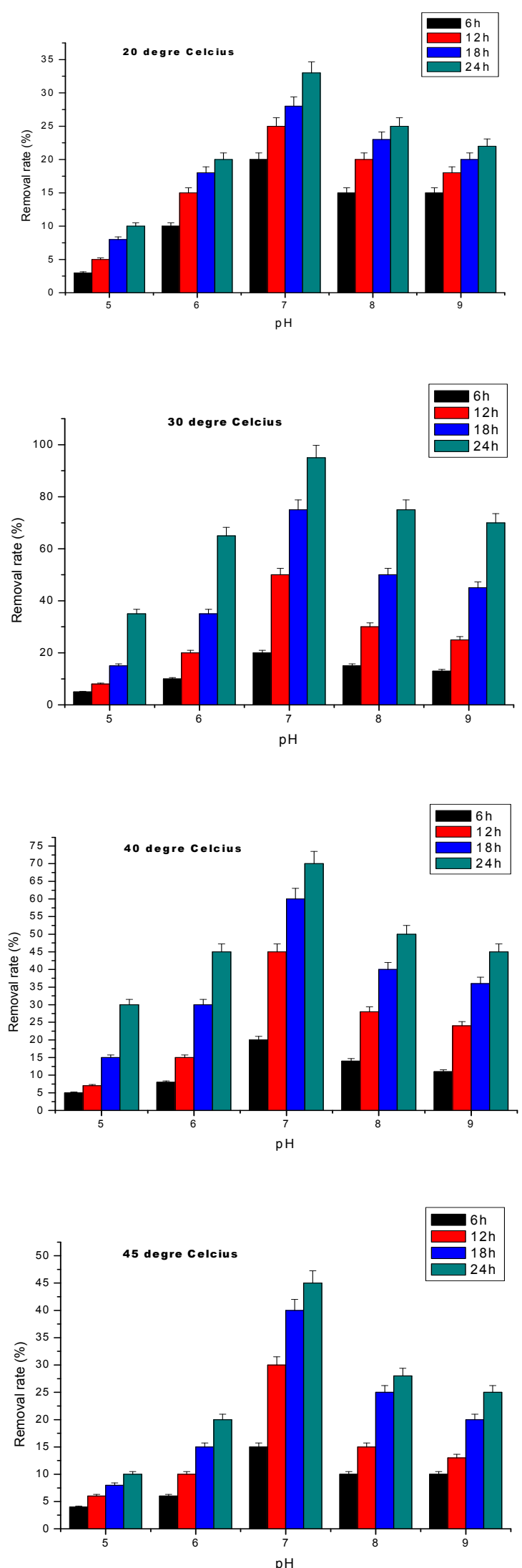

Figure 4. Effects of $\mathrm{pH}$ and temperature on $\mathrm{Cr}(\mathrm{VI})$ reduction by Bacillus cereus $\mathrm{Pf}-1$ strain supplemented by 30 $\mathrm{mg} \mathrm{Cr}(\mathrm{VI}) / \mathrm{L}$ 


\subsection{Localization of Chromium Reducing Activity}

For detecting the localization, chromate reduction essays were carried out using resting and permeabilized cells by exposing the cells to $30 \mathrm{mg} \mathrm{Cr}(\mathrm{VI}) / \mathrm{L}$ at $30^{\circ} \mathrm{C}$ and the samples were withdrawn at regular time intervals $(2-12$ h) to measure the remaining $\mathrm{Cr}$ (VI) concentrations. Figure 5 shows the concentration of residual $\mathrm{Cr}$ (VI) upon exposure of resting and permeabilized cells of the strain. As observed from Figure 5, cell permeabilization significantly increased the $\mathrm{Cr}$ (VI) reduction. Among the two reagents used for permeabilization, Toluene increased the permeabilization of bacterial cells, which resulted in higher $\mathrm{Cr}$ (VI) reduction. Upon treatment with Toluene, complete reduction was observed at $0.5 \%$ of Toluene concentrations. Chromate reduction essays were followed using initial concentration of $30 \mathrm{mg} \mathrm{Cr}$ (VI)/L with cytosolic fraction (CFE) or cell-free extract and membrane fraction $(\mathrm{CM})$. As observed from Table 2, reduction of $\mathrm{Cr}(\mathrm{VI})$ was mainly associated with soluble fraction (CFE), indicating the presence of chromate reductase in cytoplasmic fraction. No significant activity of chromate reduction was noticed in the membrane fraction derived from ultra-sonicated cells of the isolate. Heated kill cells, cell-free extracts acting as control failed to reduce $\mathrm{Cr}(\mathrm{VI})$. These results confirm the presence of soluble enzymatic mechanism in the cytoplasmic fraction (crude cell-free extract) of the strain. At the optimal temperature $30^{\circ} \mathrm{C}$ and $\mathrm{pH} 7.0$, the specific activity of $\mathrm{Cr}(\mathrm{VI})$ reduction was determined to be $0.88 \mu \mathrm{mol} \mathrm{min}{ }^{-1}$ $\mathrm{mg}^{-1}$ proteins.
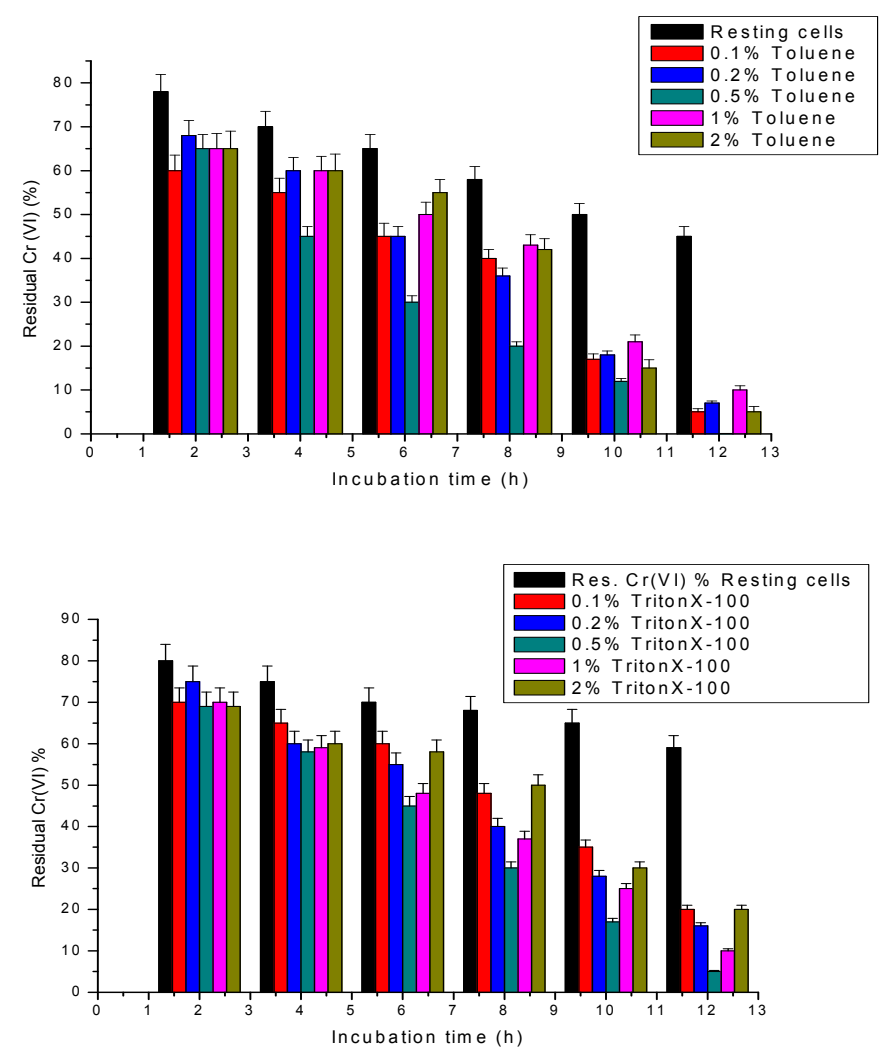

Figure 5. Hexavalent chromium reductions by resting and permeabilized cell of Pf-1 strain

$\mathrm{Cr}$ (VI) reduction activity of the soluble fraction was estimated in presence of $0.1 \mathrm{mM}$ protein denaturants and electron donors at initial $\mathrm{Cr}(\mathrm{VI})$ concentration of $30 \mathrm{mg} / \mathrm{L}$ upon incubation at $30{ }^{\circ} \mathrm{C}$ and $\mathrm{pH} 7.0$ for $30 \mathrm{~min}$ in $50 \mathrm{mM}$ phosphate buffer. Urea, a protein denaturant, inhibited the $\mathrm{Cr}(\mathrm{VI})$ reduction by $85 \%$, while another protein denaturant thiourea inhibited the $\mathrm{Cr}(\mathrm{VI})$ reduction by $95 \%$, indicating the denaturation of proteins responsible for inhibition of $\mathrm{Cr}(\mathrm{VI})$ reduction. The specific activity of $\mathrm{Cr}$ (VI) reduction in the cell-free extract of the isolate showed an increase with the addition of $0.1 \mathrm{mM} \mathrm{NADH}$; addition of $0.1 \mathrm{mM} \mathrm{NADH}$ in the reaction mixture containing cell-free extract also stimulated the reduction of $\mathrm{Cr}(\mathrm{VI})$. Additionally, glucose, a possible electron donor, during the reduction of $\mathrm{Cr}(\mathrm{VI})$, increased $\mathrm{Cr}(\mathrm{VI})$ reduction as observed from data present in Table 3. Citrate increased Cr (VI) reduction to a significant level. However, succinate had no significant effect on 
the reduction of $\mathrm{Cr}(\mathrm{VI})$ by cell-free extract.

\subsection{SEM-EDX Analysis}

The SEM images revealed that the strain has rod-shaped, elongated and uniform size in the control without $\mathrm{Cr}$ (VI) (Figure 6a). It could be clearly observed that the cells shape was considerably changed when Cr (VI) was added (Figure 6b). EDX analysis revealed an obvious peak at binding energy of $5.5 \mathrm{keV}$, which was corresponding to $\mathrm{Cr}$ for the intracellular sample of the strain that has been treated with $\mathrm{Cr}$ (VI) (Figure 6b).
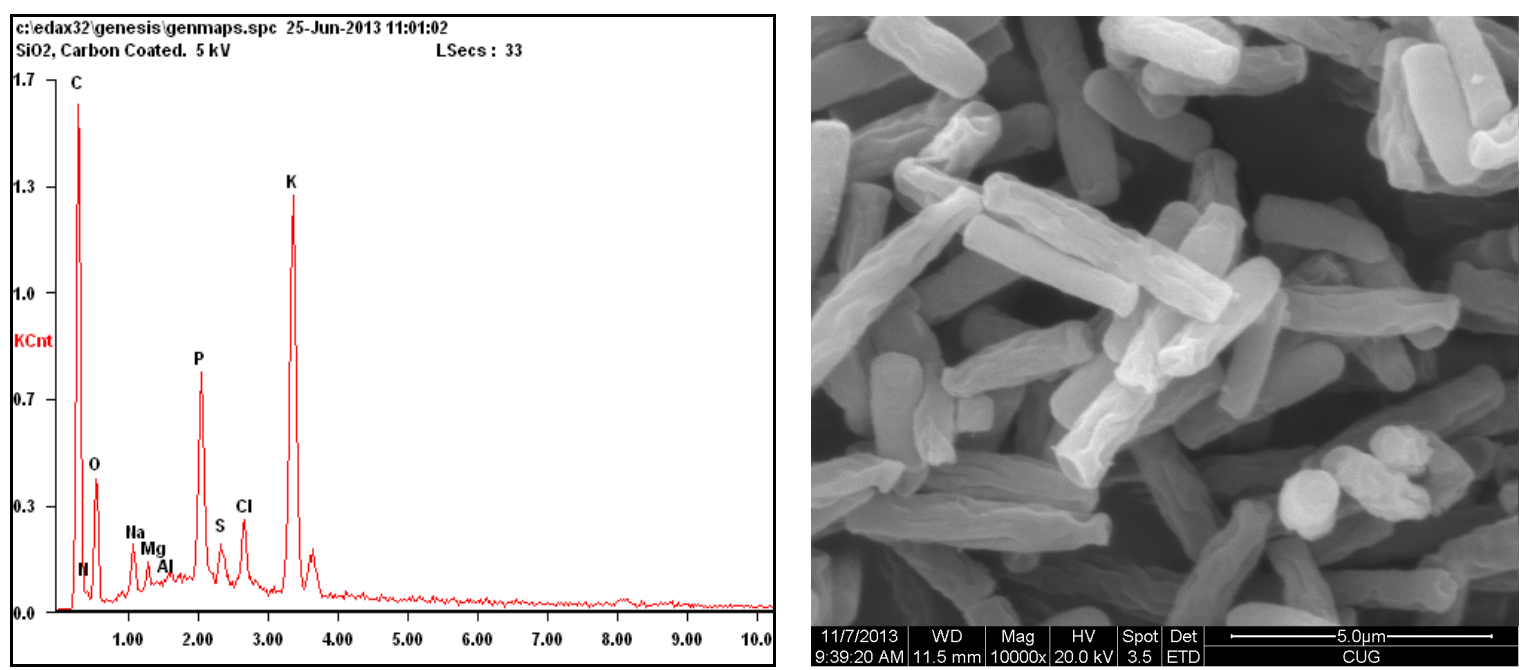

Figure 6a. SEM-EDX images without Cr (VI)
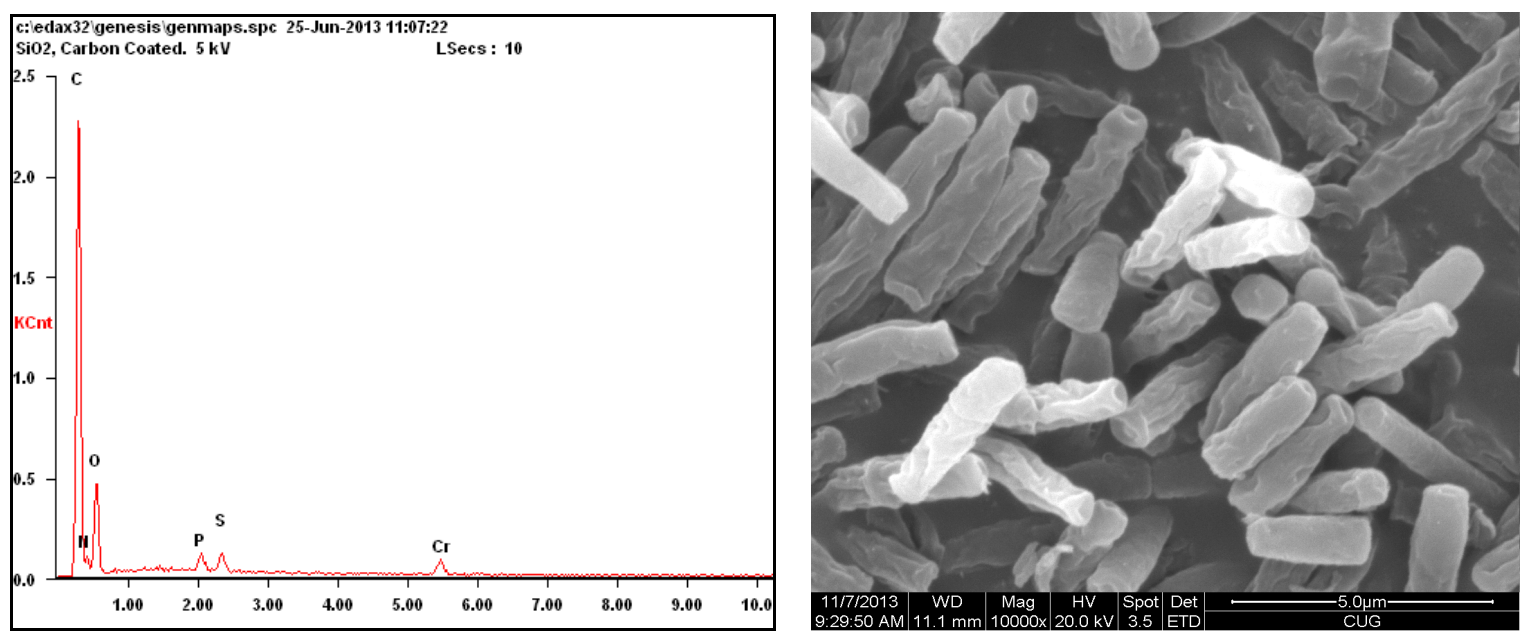

Figure 6b. SEM-EDX images treated with $\mathrm{Cr}(\mathrm{VI})$

Table 2. Sub-cellular localization of chromate reductase activity in Pf-1 strain

\begin{tabular}{cc}
\hline Cellular fractions & Chromate reductase activity $\left(\mu \mathrm{mol} \mathrm{min} \mathrm{mg}^{-1}\right.$ protein) \\
\hline Cytoplasmic fraction $(\mathrm{CFE})$ & $0.88 \pm 0.15^{*}$ \\
Membrane fraction $(\mathrm{CM})$ & $0.081 \pm 0.032$
\end{tabular}

*Standard error. 
Table 3. Protein denaturants and electron donors on chromate reductase activity in the cell-free extract

\begin{tabular}{|c|c|}
\hline Protein denaturants & Specific activity ( $\mu \mathrm{mol} \mathrm{min}^{-1} \mathrm{mg}^{-1}$ protein) \\
\hline CFE (control) & $0.33 \pm 0.16^{*}$ \\
\hline Urea & $0.082 \pm 0.025$ \\
\hline Thiourea & $0.045 \pm 0.012$ \\
\hline \multicolumn{2}{|l|}{ Electron donors } \\
\hline NADH & $0.79 \pm 0.24$ \\
\hline Glucose & $0.67 \pm 0.18$ \\
\hline Succinate & $0.32 \pm 0.109$ \\
\hline Citrate & $0.65 \pm 0.188$ \\
\hline
\end{tabular}

*Standard error.

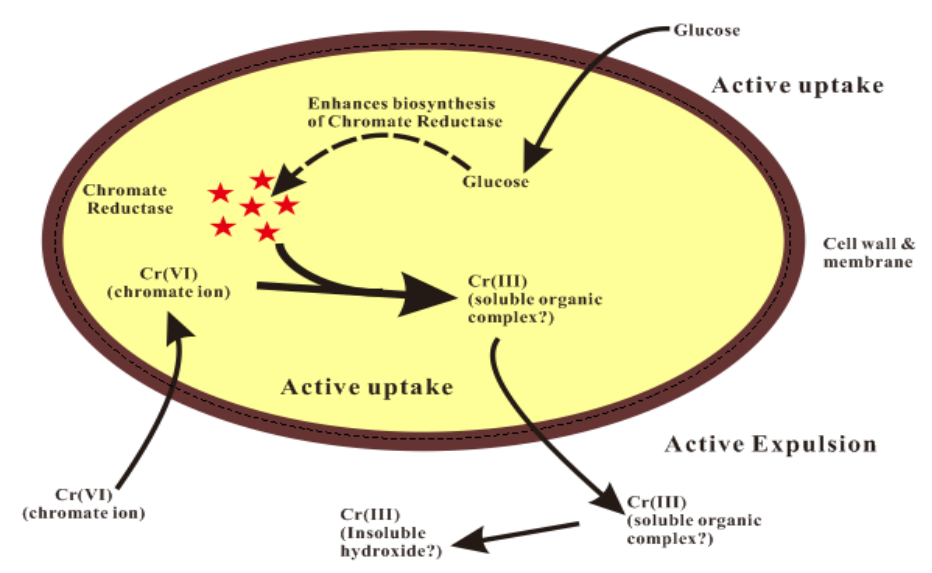

Figure 7. Mechanism of bacterial reduction of toxic $\mathrm{Cr}$ (VI) to non toxic $\mathrm{Cr}$ (III)

\section{Discussion}

Activated sludge/biosolid is a common environment for microbial communities with emergence of bacterial species having elevated metal tolerance. In the present investigation, bacterial strains tolerating and reducing $\mathrm{Cr}$ (VI) were isolated in dewatering sludge from a municipal treatment plant in Wuhan, China. The higher tolerant and reducing strain was selected for further analysis. The selected strain belongs to the genus Bacillus. Strains of the genus Bacillus are known to tolerate and reduce $\mathrm{Cr}$ (VI). However, the tolerance level and reduction ability varied with the strains identity.

In our experiments, higher $\mathrm{Cr}(\mathrm{VI})$ concentrations caused decrease in growth rate when compared to growth at lower $\mathrm{Cr}(\mathrm{VI})$ concentrations, suggesting that $\mathrm{Cr}(\mathrm{VI})$ was toxic to the cell. It is also clear from our results (Figure 3) that increase in chromate reduction was growth dependent; higher Cr (VI) reduction were noticed during the first $12 \mathrm{~h}$ corresponding to exponential phase of the microbial growth because $\mathrm{Cr}$ (VI) reduction is an active process; in the exponential phase of microbial growth, most of the cells are active and result to the increase of the reduction rate. Most likely, bacterial growth and $\mathrm{Cr}$ (VI)-induced damage are competing processes, and bacteria can cope with $\mathrm{Cr}$ (VI) exposure only as long as metabolizable carbon sources are available. Liu et al. (2006) noticed that this phenomenon might be explained as an increased time period for adaptation or repair during the exposure to high level of $\mathrm{Cr}(\mathrm{VI})$ in the growth medium.

The high level of $\mathrm{Cr}$ (VI) in the medium induces frame shift error and, to a greater extent, base pair substitution both in G-C and A-T base pairs (Deflora et al., 1990).

Hexavalent chromium reduction by $B$. cereus was investigated at different temperature $\left(20-45^{\circ} \mathrm{C}\right)$, an important factor affecting microbial $\mathrm{Cr}(\mathrm{VI})$ reduction. Maximum $\mathrm{Cr}(\mathrm{VI})$ reduction was established at $30^{\circ} \mathrm{C}$, which also corresponds to the maximum growth of the bacterial strain, confirming that $\mathrm{Cr}$ (VI) reduction was growth 
dependent. Additionally, our strain can be considered as a mesophile bacterium with a moderate optimum temperature. Such growth dependent chromate reduction has also been earlier reported by Desai et al. (2008a). It has been reported that the optimal temperature of $\mathrm{Cr}(\mathrm{VI})$ reduction could be in the range of $25-37{ }^{\circ} \mathrm{C}$ (Ibrahim et al., 2012). However, optimum temperature of $\mathrm{Cr}$ (VI) reduction of thermophilic Thermus scotoductus SA-01 (Opperman et al., 2008b) and Bacillus firmus KUCr1 (Sau et al., 2010) have been reported at 65 and $70{ }^{\circ} \mathrm{C}$, respectively.

$\mathrm{Cr}$ (VI) reduction was found to be also $\mathrm{pH}$ dependent. The growth and the reduction rate changed with the $\mathrm{pH}$ suggesting that $\mathrm{pH}$ is one of the key factors in microbial $\mathrm{Cr}(\mathrm{VI})$ reduction. $\mathrm{Pf}-1$ has his optimum growth at $\mathrm{pH}$ 7.0, therefore it can be considered as a neutrophile strain. Wang et al. (1990) reported that reduction of Cr (VI) in bacterial strain occurred at neutral $\mathrm{pH}$ 6.0-8.0 and was strongly inhibited when the $\mathrm{pH}$ fall to acidic and alkaline conditions. Murugavelh and Mohanty reported the optimum pH 6.0 for the reduction of $\mathrm{Cr}$ (VI) with free cells of Bacillus sp. Our results clearly indicated that chromate reduction was dependent on $\mathrm{pH}$, temperature, strain identity, suggesting that different strains perform differently under different temperature and $\mathrm{pH}$.

Negligible reduction was noticed in abiotic control at all temperature and $\mathrm{pH}$, confirming the direct interaction of microbes $\mathrm{Cr}$ (VI) reduction. Similar results indicating negligible reductions in abiotic control have been earlier reported by He et al. (2010), Masood and Malik (2011).

Further, $\mathrm{Cr}$ (III) readily precipitates as $\mathrm{Cr}(\mathrm{OH})_{3}$ at $\mathrm{pH} 7.0$ (Bopp et al., 1983). However, a number of recent studies suggest that $\mathrm{Cr}$ (VI) reduction by some bacteria strains such as Pseudomonas (Dogan et al., 2011) and Bacillus sp. (Desai et al., 2008a) led to the production of soluble $\mathrm{Cr}$ (III) end products instead of $\mathrm{Cr}(\mathrm{OH})_{3}$. Dogan and his coworkers found that the release of exopolymeric substances (EPS) during microbial $\mathrm{Cr}$ (VI) reduction with Pseudomonas bacteria leads to enhance solubility of Cr (III) in solution. Puzon et al. (2002) suggested that an intracellular located $E$. coli enzyme system converts $\mathrm{Cr}(\mathrm{VI})$ to a soluble and stable $\mathrm{NAD}^{+}-\mathrm{Cr}$ (III) complex, and cytochrome c-mediated $\mathrm{Cr}$ (VI) reduction produces cytochrome c Cr (III) adducts. Their findings provide evidence that chromium exposure to cells produced elevated concentration of microbial EPS. Puzon et al. (2005) suggested that Cr (VI) intracellular reduced in the cytoplasm by a bacterial enzyme, using NADH as the reductant, and, after cells lysis, form soluble $\mathrm{Cr}$ (III) end products in solution. The metal reduction can also be mediated by the surfaces of bacterial spores (Junier et al., 2009) and such mechanism may be relevant for spore forming bacteria like Bacillus.

Resting and permeabilized cell assays provided the best evidence of the presence of a $\mathrm{Cr}$ (VI) reduction mechanism in cytosolic fraction as observed in literature. Permeabilization with Toluene and Triton X-100 at different concentrations resulted in increased $\mathrm{Cr}(\mathrm{VI})$ reduction, confirming that cytoplasmic proteins were released and the strain reduced $\mathrm{Cr}$ (VI) to $\mathrm{Cr}$ (III) through soluble cytosolic reductases and not through membrane associated reductases. Moreover, the reduction with Toluene was significantly higher compared to the reduction facilitated by Triton X-100, suggesting that phospholipids were more dissolved than proteins. Toluene and Triton X-100 are known to permeabilize the membrane phospholipids and solubilizing inner membrane proteins. The inability to reduce $\mathrm{Cr}$ (VI) by boiled cell-free extract, which served as control, showed that reduction process was enzymatic and not due to adsorption or chemical reaction. The cell lysis played an important role in $\mathrm{Cr}(\mathrm{VI})$ reduction. Elangovan and his coworkers observed that chromate reductase activity was associated with soluble proteins and not with the membrane fraction. Desai et al. (2008b) suggested that a soluble chromate reductase associated with the cytoplasmic membrane catalyzed $\mathrm{Cr}$ (VI) reduction by Pseudomonas sp. G1DM21 by transferring initial one electron to $\mathrm{Cr}$ (VI) to form an intermediate $\mathrm{Cr}(\mathrm{V})$, followed by two electron transfer to $\mathrm{Cr}$ (III) formation. Our results indicate that, although the chromate-reducing fraction was located in cytosol, this fraction may have been extracellular released considering major amount of chromium being reduced during $24 \mathrm{~h}$ incubation. Additionally, the presence of $\mathrm{Cr}$ peak in the EDX image for the sample treated with $\mathrm{Cr}$ (VI) indicated that there were certain amounts of $\mathrm{Cr}$ in the cells. These findings indicate that $\mathrm{Cr}$ (VI) was transferred to $\mathrm{Cr}$ (III) by Bacillus cereus. It is possible that $\mathrm{Cr}$ (VI) was first adsorbed to the cell walls, then absorbed into the cells and reduced to $\mathrm{Cr}$ (III) by the soluble cytosolic reductase as illustrated in Figure 7.

Electron donors have been known to affect chromate reduction activity. Glucose and citrate has significant stimulatory effect on $\mathrm{Cr}$ (VI) reduction and their activities were 2 fold higher than the control experiments. Glucose, by active uptake, enhances the biosynthesis of chromate reductase as mentioned in Figure 7. Studies by Mabbett et al. (2002) show the presence of low molecular organic molecules such as citrate protected the chromate reductase enzymes from inactivation by removing toxic products of microbial reduction and a close connection between the amount of $\mathrm{Cr}(\mathrm{VI})$ reduced and equilibrium constants of $\mathrm{Cr}$-ligand complexes with more $\mathrm{Cr}$ (VI) being reduced with much stronger complexes. Succinate, on the other hand, did not show any 
noteworthy effect in $\mathrm{Cr}(\mathrm{VI})$ reduction. The $\mathrm{Cr}$ (VI) reduction by this strain of Bacillus cereus belongs to the NADH and/or glucose dependent type. An addition of NADH or glucose improved $\mathrm{Cr}$ (VI) reduction to a significant level. There have been reports supporting NADH-dependent $\mathrm{Cr}(\mathrm{VI})$ reduction from pseudomonas $s p$., E. coli, and Bacillus sp.; probably, these can use NADH as electron donor (Bae et al., 2005).

Previous reports have demonstrated that intracellular $\mathrm{Cr}(\mathrm{VI})$ accepts a single electron from an NADH molecule forming a $\mathrm{Cr}(\mathrm{V})$ intermediate, which in turn accepts two electrons from two molecules of NADH to form stable $\mathrm{Cr}$ (III) (Suzuki et al., 1992). Urea and thiourea are well known protein denaturizing agents. In our study, both inhibited the $\mathrm{Cr}$ (VI) reduction by 85 and $95 \%$, respectively.

\section{Conclusion}

The results of the current investigation clearly demonstrated that Bacillus cereus Pf-1 strain has strong potentials to reduce toxic and soluble $\mathrm{Cr}(\mathrm{VI})$ to the less toxic and less soluble $\mathrm{Cr}$ (III) and hence can be employed as a bio-agent for $\mathrm{Cr}(\mathrm{VI})$ detoxification from the contaminated effluents. Further, the findings of the current study would help the exploration of the reduction performance of the genus Bacillus and develop appropriate conditions for the treatment of contaminated effluents/soils.

\section{Acknowledgements}

This research was jointly supported by the National Natural Science Foundation of China (No: 40872157, 40830748); National Program on Key Basic Research Project of China (973 Program) (No: 2010CB428802).

\section{References}

Ackerley D. F., Gonzalez, C. F., Park, C. H., Blake, R. II., Keyhan, M., \& Martin, A. (2004). Chromate-reducing properties of soluble flavoproteins from Pseudomonas putida and Escherichia coli. Applied and Environmental Microbiology, 70(2), 873-882. http://dx.doi.org/10.1128/AEM.70.2.873-882.2004

Bae, W. C., Lee, H. K., Choe, Y. C., Jahng, D. K., Lee, S. H., Kim, S. J., ... Jeong, B. C. (2005). Purification and characterization of NADPH dependent Cr (VI) reductase from Escherichia coli ATCC 33456. Journal of Microbiology, 43(1), 21-27.

Bopp, L. H., Chakrabarty, A. M., \& Ehrlich, H. L. (1983). Chromate resistance plasmid in Pseudomonas fluorescens. Journal of Bacteriology, 155(3), 1105-1109.

Camargo, F. A., Bento, F. M., Okeke, B. C., \& Frankenberger, W. T. (2003). Chromate reduction by chromium-resistant bacteria isolated from soils contaminated with dichromate. Journal of Environmental Quality, 32(4), 1228-1233. http://dx.doi.org/10.2134/jeq2003.1228

Chachaty, E., \& Saulnier, P. (2000). Isolating chromosomal DNA from bacteria. In R. Rapley (Ed.), The nucleic acid protocols handbook (pp. 29-32). Humana, Totowa. http://dx.doi.org/10.1385/1-59259-038-1:29

Cheung, K. H., Lai, H. Y., \& Gu, J. D. (2006). Membrane-associated hexavalent chromium reductase of Bacillus megaterium TKW3 with induced expression. Journal of Microbiology and Biotechnology, 16(6), 855-862.

De Flora, S., Bagnasco, M., Serra, D., \& Zanacchi, P. (1990). Genotoxicity of chromium compounds: a review. Mutation Research, 238(2), 99-172. http://dx.doi.org/10.1016/0165-1110(90)90007-X

Desai, C., Jain, K., \& Madamwar, D. (2008a). Hexavalent chromate reductase activity in cytosolic fractions of Pseudomonas sp. G1DM21 isolated from Cr (VI) contaminated industrial landfill. Process Biochemistry, 43(7), 713-721. http://dx.doi.org/10.1016/j.procbio.2008.02.015

Desai, C., Jain, K., \& Madamwar, D. (2008b). Evaluation of in vitro Cr (VI) reduction potential in cytosolic extracts of three indigenous Bacillus sp. isolated from $\mathrm{Cr}$ (VI) polluted industrial landfill. Bioresource Technology, 99(14), 6059-6069. http://dx.doi.org/10.1016/j.biortech.2007.12.046

Dogan, N. M., Kantar, C., Gulcan, S., Dodge, C. J., Yilmaz, B. C., \& Mazmanci, M. A. (2011). Chromium (VI) bioremoval by Pseudomonas bacteria: Role of microbial exudates for natural attenuation and biotreatment of $\mathrm{Cr}$ (VI) contamination. Environmental Science and Technology, 45(6), 2278-2285. http://dx.doi.org/10.1021/es102095t

Elangovan, R., Abhipsa, S., Rohit, B., Ligy, P., \& Chandraraj, K. (2006). Reduction of Cr (VI) by a Bacillus sp. Biotechnology Letter, 28(4), 247-252. http://dx.doi.org/10.1007/s10529-005-5526-z

Gheju, M., \& Balcu, I. (2010). Hexavalent chromium reduction by scrap iron in continuous-flow system. Part 2: Effect of scrap iron shape and size. Journal of Hazardous Materials, 182(1-3), 484-493. http://dx.doi.org/10.1016/j.jhazmat.2010.06.058 
Gonzalez, C. F., Ackerley, D. F., Lynch, S. V., \& Martin, A. (2005). ChrR, a soluble quinone reductase of Pseudomonas putida that defends against $\mathrm{H}_{2} \mathrm{O}_{2}$. Journal of Biology and Chemistry, 280(24), 2590-2595. http://dx.doi.org/10.1074/jbc.M501654200

He, M., Li, X., Guo, L., Miller, S., Rensing, C., \& Wang, G. (2010). Characterization and genomic analysis of chromate resistant and reducing Bacillus cereus strain SJ1. BMC Microbiology, 10, 221.

Ibrahim, A. S. S., Mohamed, A. E., Yahya, B. E., Al-Salamah, A. A., \& Garabed, A. (2012). Hexavalent chromium reduction by alkaliphilic Amphibacillus sp $\mathrm{KSUCr}_{3}$ is mediated by copper-dependent membrane-associated chromate reductase. Extremophiles, 16(4), 659-668. http://dx.doi.org/10.1007/s00792-012-0464-x

Ilias, M., Rafiqullah, I. M., Debnath, B. C., Mannan, K. S., \& Hoq, M. (2011). Isolation and characterization of chromium (VI)-reducing bacteria from tannery effluents. Indian Journal of Microbiology, 5(1), 76-81. http://dx.doi.org/10.1007/s12088-011-0095-4

Ishibashi, Y., Cerventes, C., \& Silver, S. (1990). Chromium reduction in Speudomonas putida. Applied and Environmental Microbiology, 6, 2260-2270.

Junier, P., Frutschi, M., Wigginton, N. S., Schofield, E. J., Bargar, J. R., \& Latmani, B. R. (2009). Metal reduction by spores of Desulfotomaculum reducen. Environmental Microbiology, 11(12), 3007-3017. http://dx.doi.org/10.1111/j.1462-2920.2009.02003.x

Kwak, Y. H., Lee, D. S., \& Kim, H. B. (2003). Vibrio harveyi nitroreductase is also a chromate reductase. $\begin{array}{llll}\text { Applied and } \quad \text { Environmental } & \text { Microbiology, }\end{array}$ http://dx.doi.org/10.1128/AEM.69.8.4390-4395.2003

Liu, Y. G., Xu, W. H., Zeng, G. M., Li, X., \& Gao, H. (2006). Cr (VI) reduction by Bacillus sp. isolated from $\begin{array}{llll}\text { chromium landfill. } \quad \text { Process } & \text { Biochemistry, }\end{array}$ http://dx.doi.org/10.1016/j.procbio.2006.04.020

Mabbett, A. N., Lloyd, J. R., \& Macaskie, L. E. (2002). Effect of complexing agents on reduction of Cr (VI) by Desulfovibrio vulgaris ATCC 29579. Biotechnology and Bioengineering, 79(4), 389-397. http://dx.doi.org/10.1002/bit.10361

Mangaiyarkarasi, M. M. S., Vincent, S., \& Janarthanan, S. (2011). Bioreduction of Cr (VI) by alkaliphilic Bacillus subtilis and interaction of the membrane groups. Saud Journal of Biological Science, 18(2), 157-167. http://dx.doi.org/10.1016/j.sjbs.2010.12.003

Masood, F., \& Malik, A. (2011). Hexavalent chromium reduction by Bacillus sp. strain FM1 isolated from heavy-metal contaminated soil. Bulletin of Environmental Contaminant and Toxicology, 86(1), 114-119. http://dx.doi.org/10.1007/s00128-010-0181-z

Megharaj, M., Avudainayagam, S., \& Naidu, R. (2003). Toxicity of hexavalent chromium and its reduction by bacteria isolated from soil contaminated with tannery waste. Current Microbiology, 47(1), 51-54. http://dx.doi.org/10.1007/s00284-002-3889-0

Murthy, S., Bali, G., \& Sarangi, S. K. (2012). Biosorption of lead by Bacillus cereus isolated from industrial effluents. British Biotechnology Journal, 2(2), 73-84.

Ohtake, H., Cervantes, C., \& Silver, S. (1987). Decreased chromate uptake in Pseudomonas fluorescens carrying a chromate resistance plasmid. Journal of Bacteriology, 169(8), 3853-3856.

Olajuyigbe, F. M., \& Ajele, J. O. (2005). Production dynamics of extracellular protease from Bacillus species. African Journal of Biotechnology, 4(8), 776-779. http://dx.doi.org/10.4314\%2Fajb.v4i8.15180

Opperman, D. J., Piater, L. A., \& Van Heerden, E. (2008). A novel chromate reductase from Thermus scotoductus SA-01 related to old yellow enzyme. Journal of Bacteriology, 190(8), 3076-3082. http://dx.doi.org/10.1128/JB.01766-07

Ovreas, L., Forney, L., Daae, F. L., \& Torsvik, V. (1997). Distribution of bacterioplankton in meromictic Lake Sælenvannet, as determined by denaturing gradient gel electrophoresis of PCR-amplified gene fragments coding for 16s rRNA. Applied and Environmental Microbiology, 63(9), 3367-3373.

Pal, A., Dutta, S., \& Paul, A. K. (2005). Reduction of hexavalent chromium by cell free extract of Bacillus sphaericus AND 303 isolated from serpentine soil. Current Microbiology, 51(5), 327-330. http://dx.doi.org/10.1007/s00284-005-0048-4 
Patra, R. C., Malik, B., Beer, M., Megharaj, M., \& Naidu, R. (2010). Molecular characterization of chromium (VI) reducing potential in Gram positive bacteria isolated from contaminated sites. Soil Biology and Biochemistry, 42(10), 1857-1863. http://dx.doi.org/10.1016/j.soilbio.2010.07.005

Pei, Q. H., Shahir, S., \& Santhana, A. S. (2009). Chromium (VI) resistance and removal by Acinetobacter haemolyticus. World Journal of Microbiology and Biotechnology, 25(6), 1085-1093. http://dx.doi.org/10.1007/s11274-009-9989-2

Priester, J. H., Olson, S., Webb, S. M., Neu, M. P., Hersman, L. E., \& Ve Holden, P. A. (2006). Enhanced exopolymer production and chromium stabilization in Pseudomonas putida unsaturated biofilms. Applied and Environmental Microbiology, 72(3), 1988-1996. http://dx.doi.org/10.1128/AEM.72.3.1988-1996.2006

Puzon, G. J., Petersen, J. N., Roberts, A. G., Kramer, D. M., \& Xun, L. (2002). A bacterial flavin reductase system reduces chromates (III)-NAD+ complex. Biochemistry and Biophysics Research, 294(1), 76-81. http://dx.doi.org/10.1016/j.soilbio.2010.07.005

Puzon, G. J., Roberts, A. G., Kramer, D. M., \& Xun, L. (2005). Formation of soluble organo-chromium (III) complexes after chromate reduction in the presence of cellular organics. Environmental Science and Technology, 39(8), 2811-2817. http://dx.doi.org/10.1021/es048967g

Sarangi, A., \& Krishnan, C. (2008). Comparison of in vitro Cr (VI) reduction by CFEs of chromate resistant bacteria isolated from chromate contaminated soil. Bioresource Technology, 99(10), 4130-4137. http://dx.doi.org/10.1016/j.biortech.2007.08.059

Sau, G. B., Chatterjee, S., \& Mukherjee, S. K. (2010). Chromate reduction by cell-free extract of Bacillus firmus KUCr1. Polish Journal of Microbiology, 59(3), 185-190.

Soni, S. K., Rakshapal, S., Ashtosh, A., Mangal, S., \& Alok, K. (2013). In vitro Cr (VI) reduction by cell-free extracts of chromate-reducing bacteria isolated from tannery effluent irrigated soil. Environmental Science and Pollution Research, 20(3), 1661-1674. http://dx.doi.org/10.1007/s11356-012-1178-4

Suziki, T., Miyata, N., Horitsu, H., Kawai, K., Takamizawa, K., Tai, Y., \& Okazaki, M. (1992). NAD (P) H-dependent chromium (VI) reductase of Pseudomonas ambigua G-1: A $\mathrm{Cr}$ (V) intermediate is formed during the reduction of $\mathrm{Cr}$ (VI) to $\mathrm{Cr}$ (III). Journal of Bacteriology, 174(16), 5340-5345.

Tamura, K., Peterson, D., Peterson, N., Stecher, G., Nei, M., \& Kumar, S. (2011). MEGA5: Molecular Evolutionary Genetics Analysis using maximum likelihood, evolutionary distance, and maximum parsimony methods. Molecular Biology and Evolution, 28(10), 2731-2739. http://dx.doi.org/10.1093/molbev/msr121

Wang, P. C., Mori, T., Toda, K., \& Ohtake, H. (1990). Membrane-associated chromate reductase activity from Enterobacter cloacae. Journal of Bacteriology, 172(3), 162-1670.

\section{Copyrights}

Copyright for this article is retained by the author(s), with first publication rights granted to the journal.

This is an open-access article distributed under the terms and conditions of the Creative Commons Attribution license (http://creativecommons.org/licenses/by/3.0/). 